\title{
A Critical Appraisal of The Anti-Piracy Law of Nigeria
}

\author{
Victor Nonso Enebeli, PhD* David Chibuike Njoku**
}

\begin{abstract}
Nigeria's June 2019 law on piracy and other maritime offences is an important step in securing the country's coastline and seas. The Ant-Piracy law on Suppression of Piracy and Other Maritime Offences Act, ${ }^{l} 2019$ (POMO Act) aims to 'prevent and suppress piracy, armed robbery and any other unlawful act against a ship, aircraft and any other maritime craft, including fixed and floating platforms.' It also observed that this law gives effect to the United Nations Convention on the Law of the Sea, 1982 (UNCLOS) and the Convention for the Suppression of Unlawful Acts against the Safety of Maritime Navigation, 1988 (SUA). Despite the enactment of this huge law and policies targeted at ameliorating the numerous problems at Nigeria's coastline and seas, the situation in Nigeria seems degenerating owing to the fact that there are no adequate compliance of the laws as well as the ineffective implementation or enforcement of the law. This paper seeks to critically evaluate the impacts of the Act and also its weaknesses. It also discusses Nigeria's capacity to implement its new law and detect and prosecute crimes. Analysis includes an evaluation of the steps taken by the governments of the region and the effectiveness of the implemented strategies to counter the threat posed by piracy in the region. In identifying the barriers and challenges to combat piracy, a comprehensive arrangement based effective cooperation is proposed in the paper.
\end{abstract}

Keywords: PIRACY LAW, NIGERIA

DOI: $10.7176 / \mathrm{JLPG} / 113-06$

Publication date:September $30^{\text {th }} 2021$

\subsection{Introduction}

The Suppression of Piracy and Other Maritime Offences Bill was assented to by President Muhammadu Buhari of Nigeria in July 2019 thereby enabling Nigeria to establish a domestic legal framework for dealing with piracy and other maritime crimes. It took almost a decade of advocacy to implement such a law in order to curb and deter sea piracy, armed robbery and other unlawful acts at sea.

The key objective of the Act is to give effect to the United Nations Convention on the Law of the Sea (UNCLOS $^{2}$ and the SUA Convention ${ }^{3}$ in Nigeria. In assenting to the Bill, the president successfully concluded almost a decade of advocacy to implement such a law in order to curb and deter sea piracy, armed robbery at sea, and other unlawful acts at sea. ${ }^{4}$ The focus of this article is to assess the adequacy or otherwise of the Act in the face of these and other emerging maritime threats. The Suppression of Piracy and Other Maritime Offences Act $2019^{5}$ gives effect to the relevant provisions of several international conventions already ratified by Nigeria. It is significant because it has:

- $\quad$ ended the controversy around whether the crime of sea piracy is defined in any local legislation; and

- bestowed on the Federal High Court ${ }^{6}$ exclusive jurisdiction to determine matters of armed robbery and other unlawful acts at sea.

*PhD \& LLM (Coventry), BL (Nigeria), LLB (London Met), Lecturer, Department of Public Law, Faculty of Law, Rivers State University. Email: victor.enebeli@yahoo.co.uk, Phone: 09020176657

**LL.M (RSU) in view; BL (Abuja); LL.B (UK); Dip-in-Law (UK). Senior Associate Tuduru Ede, SAN \& Co. Port Harcourt, Rivers State, Nigeria. Email: david.chibuike22@yahoo.com/ikemefula20@yahoo.com. 08065357894, 08052339985

${ }^{1}$ https://lawnigeria.com/2019/12/suppression-of-piracy-and-other-maritime-offences-act-2019/ accessed 04/08/2021

2 Adopted in Montego Bay, Jamaica, on 10 December, 1982; entry into force 11 November, 1994. 157 States Parties.

${ }^{3}$ The Convention for the Suppression of Unlawful Acts against the Safety of Maritime Navigation, 1988 and its Fixed Platforms Located on the Continental Shelf Protocol (subsequently consolidated into the 2005 SUA Convention).

4 V Onyegbado, 'Suppression of Piracy and Other Maritime Offences Act 2019: A Review, 'https://www.internationallawoffice.com accessed 28 July, 2021

${ }^{5}$ Suppression of Piracy and Other Maritime Offences Act, 2019

${ }^{6}$ Section 251, Constitution of the Federal Republic of Nigeria, 1999 (as amended) 


\subsection{Threats to Maritime Navigation}

Shipping accounts for the transportation of over 90 percent of world trade in volume terms. It is also noteworthy that the seas host important economic infrastructure such as offshore oil and gas production platforms, underwater fibre-optic cables carrying 95 percent of the world's intercontinental communications traffic (emails, phone calls, money transfers) and pipelines. ${ }^{1}$ In view of its importance as the nerve centre of world trade, the safety and security at sea of vessels, cargo, passengers and crew, and maritime infrastructure and facilities have remained of paramount concern to the international community.

The need to secure the seas and shipping against emerging threats to maritime security has, therefore, assumed much significance. In his 2008 report on Oceans and the Law of the Sea, ${ }^{2}$ the United Nations Secretary-General identified seven specific threats to maritime security as follows: piracy and armed robbery against ships, terrorism, illicit trafficking in arms and weapons of mass destruction (WMDs), illicit trafficking of narcotic drugs and psychotropic substances, smuggling and trafficking of persons by sea, illegal, unreported and unregulated fishing (IUU Fishing), and intentional and unlawful damage to the marine environment. One may also include other threats such as low-intensity or irregular maritime militia and stowaways. Two of the most violent of these threats, however, are piracy and terrorism.

Piracy as a general term constitutes a particular form of maritime violence usually characterized by aggression, plunder, hostage-taking and death. Pirate attacks threaten seafarers, the security of navigation and the marine environment, and also has the potential to disrupt the provision of humanitarian aid, fishing, tourism and marine scientific research. The alteration of navigational routes in order to bypass areas of suspected pirate activity also affect commerce. ${ }^{3}$

Terrorism, on the other hand, has been described as "political piracy. ${ }^{4}$ The crime of terrorism as has been shown by the September 11 happenings is a crime that has far-reaching international implications affecting not only the nation in which the atrocious acts are committed but also the international community in general. ${ }^{5}$ Terrorism simply means deliberately and violently targeting civilians for political purposes. Terrorism can be committed during an armed conflict or at peace times. It can be widespread and systematic or simply sporadic. ${ }^{6}$ There is, however, no internationally recognized definition of terrorism.

The concept of maritime terrorism was initially understood within the context of piracy whereby any unauthorized act of violence on the high seas would be characterized as piracy. ${ }^{7}$ However, as the formal definition of piracy under international law came to be understood as limited to acts of violence perpetrated for financial purposes, there were still acts of violence at sea undertaken for political reasons. These violent acts, if performed outside the territorial sea, were not recognized as crimes over which all states could exercise jurisdiction, as is the case with piracy. Instead, these acts came to be branded as maritime terrorism. Maritime terrorism has been described as 'the systematic use or threat to use acts of violence against international shipping and maritime services by an individual or group to induce fear and intimidation in a civilian population in order to achieve political ambitions or objectives. ${ }^{8}$

The issues surrounding maritime terrorism and the rights of states to prescribe and enforce jurisdiction over these acts of violence outside the territorial sea came most strongly to the fore in contemporary international law with the hijacking of the Achille Lauro ${ }^{9}$ and the murder of a United States national on board by Palestinian Liberation Forces in 1985. Terrorist acts have become more common since the Achille Lauro incident. The Tamil Tigers (Liberation Tigers of Tamil Eelam-LTTE) in Sri Lanka particularly utilized terrorist attacks against shipping as part of their liberation struggle; inter-island ferries in the Philippines have been targeted by terrorists; and,

${ }^{1}$ R Martinage, 'Under the Sea: The Vulnerability of the Commons,' (2015) (1) Foreign Affairs 94, 117.

$2 \mathrm{https}$ ://www.un.org/Dept/los/general assembly/general assembly reports.htm. accessed 28 July, 2021

3 P Mallia, 'The Fight Against Piracy and Armed Robbery Against Ships Off the Coast of Somalia: International Cooperation Illustrated', in Gutierrez, Norman A. Martinez, ed.; Serving the Rule of International Maritime Law: Essays in Honour of Professor David Attard, Rouledge, New York, United States, (2010) 216.

${ }^{4}$ Z Keyuan, 'New Developments in the International Law of Piracy,' Chinese Journal of International Law (2009) 13

5 Egede, 'A Need for an International Tribunal for the Trial of Terrorists, The Guardian (Nigeria, 22 January, 2002) 77

${ }^{6}$ M Taina Garcia; 'Towards an International Court Against Terrorism: An Analysis of the added-value of Establishing Such a Court.' https://www.academia.edu accessed 30 July, 2021

${ }^{7}$ N Klein, Maritime Security and the Law of the Sea, (Oxford University Press, Oxford, England, 2011) 147

${ }^{8}$ C C Joyner, 'Suppression of Terrorism on the High Seas: The 1988 IMO Convention on the Safety of Maritime Navigation,' (1989) (19) Israel Yearbook on Human Rights 341, 348.

${ }^{9}$ See Table 1. 
guerrillas alleged to be affiliated with Al Qaeda launched a suicide attack in 2000 against the US Navy destroyer USS Cole in Yemen, and an attempted attack against the USS Sullivan in 1999.

Subsequent to the September 11, 2001 attack on the World Trade Centre, New York ('September 11'), a terrorist attack was perpetrated against the French supertanker Limburg as it neared a Yemeni port through the use of small vessels packed with explosives. Attacks have also been perpetrated at various ports through car bombs, parcel bombs, and suicide bombers. ${ }^{1}$

A timeline of select incidents affecting maritime navigation is contained in Table 1 below.

Table 1: Timeline of Select Terrorist Incidents that Affected the Maritime Industry Worldwide

\begin{tabular}{|c|c|c|}
\hline 1985 & Achille Lauro & $\begin{array}{l}\text { On October 7, 1985, members of the Palestine Liberation Front (PLF), } \\
\text { a faction of the Palestine Liberation Organisation (PLO), hijacked the } \\
\text { Achille Lauro while sailing from Alexandria to Port Said, Egypt. The } \\
\text { hijackers had boarded the Achille Lauro in Genoa, Italy, managing to } \\
\text { smuggle on board automatic weapons, grenades and other explosives, } \\
\text { and intending to stay aboard as passengers until the cruise liner } \\
\text { reached Ashdod, Israel. In Israel, they 'planned either to shoot up the } \\
\text { harbour to take Israelis hostage'. The Palestinians intended to hold the } \\
\text { Israelis as hostages to bargain for the release of } 50 \text { Palestinians held in } \\
\text { Israeli jails. } \\
\text { The four PLO members aborted their plans and seized the ship when } \\
\text { the crew discovered their weapons after the Achille Lauro left } \\
\text { Alexandria. On the high seas, while holding the ship's crew and } \\
\text { passengers hostage, the hijackers threatened to kill the passengers } \\
\text { unless Israel released } 50 \text { Palestinian prisoners. They also threatened to } \\
\text { blow up the ship if anyone attempted a rescue mission. On the } \\
\text { afternoon of October } 8 \text {, } 1985 \text {, Israel not having met their demands, the } \\
\text { hijackers killed an American passenger on board. The hijackers were } \\
\text { eventually apprehended and some of the perpetrators of the Achille } \\
\text { Lauro were brought to justice in Italian courts. }\end{array}$ \\
\hline 1988 & City of Poros & $\begin{array}{l}\text { In July } 1988 \text {, three members of the Abu Nidal organisation boarded } \\
\text { the vessel at a resort island, posing as passengers bound for Athens. } \\
\text { Once at sea they opened fire with firearms and grenades, killing nine } \\
\text { persons and wounding nearly } 100 \text {. They then jumped overboard and } \\
\text { were picked by a small vessel operated by an accomplice. }\end{array}$ \\
\hline 2000 & USS Cole & $\begin{array}{l}\text { On October 12, 2000, the United States Navy guided-missile } \\
\text { destroyer, USS Cole (DDG-67), was targeted by a suicide attack while } \\
\text { it was being refuelled in the port of Aden, Yemen. Two members of } \\
\text { Al-Qaida drove towards the USS Cole with a small craft containing } \\
200-300 \text { kilograms of explosives. Despite numerous warnings and } \\
\text { prohibitions, the boat approached and when it hit the USS Cole, it } \\
\text { exploded killing } 17 \text { and wounding } 39 \text { American sailors. }\end{array}$ \\
\hline 2001 & $\begin{array}{l}\text { World Trade Centre, New } \\
\text { York, US }\end{array}$ & $\begin{array}{l}\text { Use of seized aircraft by terrorists as impact and incendiary weapons } \\
\text { in attacks in September 11, } 2001 \text { against the World Trade Centre in } \\
\text { New York. }\end{array}$ \\
\hline 2002 & Limburg & $\begin{array}{l}\text { Use of an explosive laden ship to attack the oil tanker Limburg in } \\
\text { 2002. One crew member killed. }\end{array}$ \\
\hline 2004 & SuperFerry 14 & $\begin{array}{l}\text { Bombing in February } 2004 \text { of the vessel SuperFerry 14. After sailing } \\
\text { from Manila Bay on a domestic route, a bomb concealed in a } \\
\text { television set exploded. } 116 \text { persons among the almost } 900 \\
\text { passengers and crew on board died as a result of the explosion, } \\
\text { resulting fire and sinking of the vessel. Responsibility for the attack } \\
\text { was claimed by the Abu Sayaaf separatist group. }\end{array}$ \\
\hline
\end{tabular}

Following the Achille Lauro incident and September 11, there was cognizance of the range of terrorist acts that could be perpetrated, and that the existing legal regimes were inadequate to meet these threats.

The most important treaty which codified the international law of piracy was the Geneva Convention on the High Seas (HSC), ${ }^{2}$ which contains eight provisions concerning the suppression of piracy on the high seas. It was eventually superseded by the 1982 United Nations Convention on the Law of the Sea (UNCLOS) which simply

\footnotetext{
${ }^{1}$ Attacks on the Israeli port of Ashdod, and the Pakistani ports of Karachi and Gwadar

${ }^{2}$ Geneva Convention on the High Seas, Adopted in Geneva on 29 April, 1958; entry into force 30 September, 1962.63 states parties.
} 
incorporated the anti-piracy provisions of the 1958 Convention without any change. UNCLOS was an effort by the international community to reach agreement on one instrument on a comprehensive regime dealing with all matters relating to the law of the sea. This Convention provides for the peaceful uses of the sea and the area of the seabed, ocean floor and the subsoil thereof and sets out a legal framework within which all activities in the oceans and seas must be carried out. The provisions of UNCLOS establish different maritime zones, whose maximum breadth is measured from a set of baselines along the coast of a state. ${ }^{1}$ The high seas provisions dealing with the prohibition of transporting slaves and piracy found in the HSC have largely been incorporated in Part VII of UNCLOS. ${ }^{2}$ States are obliged to cooperate in the suppression of piracy, ${ }^{3}$ and can use their warships and military aircraft or similar governmentally authorized ships or aircraft to seize a pirate ship or aircraft and arrest pirates. ${ }^{4}$

Although it was still in the ratification process in 1985, when the Achille Lauro hijacking occurred, both its provisions and those of the HSC were examined at that time for guidance concerning vessel hijacking and the murder of a passenger as international crimes. The legal framework for the repression of piracy under international law is set out in Articles 100-107 of UNCLOS. These Articles, which are based on Articles 14-21 of the HSC, are generally considered to reflect customary law of the sea applicable to all states. Article 101 UNCLOS defined acts of piracy to consist of 'illegal acts of violence, detention or any act of depredation, committed for private ends by the crew or the passengers of a private ship or a private aircraft, and directed on the high seas, against another ship or aircraft, or against persons or property on board such ship or aircraft.'

This legal definition of piracy must be distinguished from the concept of armed robbery against ships. This is a term used by the IMO in its Code of Practice for the Investigation of Crimes of Piracy and Armed Robbery against Ships. ${ }^{5}$ This Code, which has no legal status, defines armed robbery against ships as 'any illegal act of violence or detention or any act of depredation, or threat thereof, other than an act of piracy, committed for private ends and directed against a ship or against persons or property on board such a ship, within a State's internal waters, archipelagic waters and territorial sea; and any act of inciting or of intentionally facilitating an act described above.'

The Achille Lauro case involved numerous controversies concerning whether Italy and Egypt had agreed to forego prosecution, whether such a promise was conditioned on no one being harmed during the seizure, concerning the role of the Palestinian Liberation Organization, concerning legal obligation of the states involved with regard to extradition and international cooperation, and concerning whether the hijacking was a universal offence under international customary law or only an offence depending on its definition by the national law of the various states involved.

The possibility of establishing universal jurisdiction was then related to the Convention on the High Seas provision on piracy. However, the Achille Lauro incident could not be characterized as piracy because the crimes were not committed for private ends ${ }^{6}$ and did not involve a pirate ship. Another controversial issue was related to the fact that as the terrorists with their weapon freely boarded the Achille Lauro in Italy the crimes could not be considered as entirely perpetrated in the high seas, thus creating a further impediment to the exercise of universal jurisdiction.

Also, in the City of Poros $^{7}$ incident, two elements of the definition of piracy found in the HSC and the UNCLOS were either missing or in doubt. The element of persons from one ship attacking another ship was absent. In addition, the violence was indisputably committed for a political purpose and not for economic gain, so the element that the violence be 'committed for private ends' also seems to be lacking.

When the Achille Lauro and City of Poros incidents were analyzed, it was evident that they could not be classified as piracy. Neither customary maritime law nor the then applicable HSC treated such incidents as international crimes and no universal instrument required their criminalization or dealt with issues of jurisdiction

\footnotetext{
${ }^{1}$ These zones, especially the territorial sea and continental shelf, are relevant in establishing the scope of application of both the SUA Conventions and the Fixed Platforms Protocols.

${ }^{2}$ Articles 99 and 100-107, UNCLOS.

${ }^{3}$ Article 100, UNCLOS.

${ }^{4}$ Article 105, UNCLOS.

${ }^{5}$ Assembly Resolution A.1025 (26).

${ }^{6} \mathrm{~J}$ Kraska and R Pedro, Pirates are motivated by private interest to attack ships on the High Seas or in Territorial Waters. International Maritime Security Law, Martins Nijhoff, Leide, (The Netherlands, 2013) 358.

${ }^{7}$ See Table 1.
} 
and criminal justice cooperation. Moreover, it was evident that this gap in international law would not be filled even when the UNCLOS would come into effect, as its definition of piracy was the same as that in the HSC.

Accordingly, consideration was given to the need for an additional international instrument to address this new manifestation of terrorist violence. That task was vested in the IMO. The International Maritime Organization (IMO) is a specialized agency of the United Nations established in Geneva in 1948 to adopt treaties and recommendations containing rules and standards for the safety of navigation and the prevention of marine pollution from ships. One of its stated goals is to 'encourage the general adoption of the highest practicable standards in matters concerning maritime safety ... ${ }^{1}$ While 'maritime safety' refers to the prevention and suppression of risks affecting maritime navigation in general, the notion of maritime security is associated with risks to navigation resulting of wilful misconduct, thereby including prevention and suppression of all intentional unlawful acts affecting maritime navigation.

The Organization has been particularly active in the adoption of guidelines to prevent and suppress piracy and armed robbery against ships. It has adopted several international conventions relevant to piracy for its member countries to implement, including the SUA Convention, International Convention for the Safety of Life at Sea (SOLAS), ${ }^{2}$ the International Convention on Standards of Training, Certification and Watch-keeping for Seafarers, and the International Ship and Port Facility Security Code (ISPS Code). ${ }^{3}$

The Convention for the Suppression of Unlawful Acts against the Safety of Maritime Navigation, 1988 and its Fixed Platforms Located on the Continental Shelf Protocol (subsequently consolidated into the 2005 SUA Conventions) were subsequently adopted under the auspices of the International Maritime Organization (IMO) to fill the gap in the international legal regime to combat maritime terrorism which became noticeable following the Achille Lauro incident of 1985. The SUA Conventions have since become an important part of the legal framework for the investigation, arrest and prosecution of maritime transport-related crimes, and also for international cooperation as regards the extradition of offenders.

SUA Conventions were adopted and now form the fundamental legal regime developed by IMO to protect the maritime industry and combat violent maritime transport-related crimes such as terrorism, piracy and other international crimes. ${ }^{4}$ The process leading to their preparation, adoption and ratification would be analyzed next.

\subsection{International Legal Instruments to Combat Maritime Crimes: Convention for the Suppression of Unlawful Acts Against the Safety of Maritime Navigation (1988 SUA Convention)}

Within days of the resolution of the Achille Lauro hijacking in October 1985, the IMO Assembly adopted Resolution A. 584 (14) on 20 November 1985 condemning the hijacking and directing the IMO Maritime Safety Committee to develop technical security measures. The United Nations General Assembly, on 9 December, 1985, also adopted Resolution 40/61, which requested the IMO to 'study the problems of terrorism aboard or against ships with a view to making recommendations on appropriate measures.'

Following proposals received from some governments and the International Transport Workers Federation for an international maritime safety convention modelled on the Tokyo ${ }^{5}$ and Montreal Conventions ${ }^{6}$ and the 1979 Convention Against the Taking of Hostages, ${ }^{7}$ an Ad Hoc Preparatory Committee was created to work on the convention. The result of the Committee's work is the Convention for the Suppression of Unlawful Acts against the Safety of Maritime Navigation (and its Fixed Platforms Located on the Continental Shelf Protocol) (1988 SUA Convention).

The SUA acronym stands for 'Suppression of Unlawful Acts' and the first of the SUA treaties, the Convention for the Suppression of Unlawful Acts Against the Safety of Maritime Navigation, 1988 (1988 SUA

\footnotetext{
${ }^{1}$ Article 1 of the IMO Convention.

${ }^{2}$ SUA Convention, International Convention for the Safety of Life at Sea (SOLAS), Adopted in 1974, entered into force 25 May 1980. 162 State Parties.

${ }^{3}$ International Ship and Port Facility Security Code (ISPS Code), Entered into force 1 July 2004.

${ }^{4}$ Message of the IMO Secretary-General to the Counter-Terrorism Legal Training Curriculum [Transport-Related (Civil Aviation and Maritime) Terrorism Offences, United Nations, UNODC, 2014, p v. www.unodc.org. accessed on 31 July, 2021

${ }^{5}$ Convention on Offences and Certain Other Acts Committed on Board Aircraft, adopted in Tokyo 14 September, 1963; entry into force 4 December, 1969. 186 State Parties.

${ }^{6}$ Convention for the Suppression of Unlawful Acts Against the Safety of Civil Aviation, adopted in Montreal, Canada September 23, 1971; entry into force 26 January, 1973. 188 State Parties.

${ }^{7}$ Adopted by the General Assembly of the United Nations on December 17, 1979; entry into force 3 June, 1983. 174 State Parties.
} 
Convention), ${ }^{1}$ provides the legal basis for action to be taken against persons committing unlawful acts against ships, including the seizure of ships by force, acts of violence against persons on board ships and the placing of devices on board which are likely to destroy or damage the ship. ${ }^{2}$ A Protocol to this treaty, namely, the Protocol for the Suppression of Unlawful Acts against Fixed Platforms Located on the Continental Shelf, 1988 (1988 Fixed Platforms Protocol), extends the application of the SUA Convention to unlawful acts against the safety of fixed platforms located on the continental shelf. Only parties to the 1988 SUA Convention may become Parties to this Protocol. ${ }^{3}$

The reason for the development of the Convention is well enshrined in its preamble which notes the worldwide escalation of acts of terrorism in all its forms and underscores the need to develop international cooperation between states in devising and adopting effective and practical measures for the prevention of all unlawful acts against the safety of maritime navigation, and the prosecution and punishment of their perpetrators.

The Convention, which applies to ships 'navigating into, through or from waters beyond the outer limit of the territorial sea of a single State, or beyond the lateral limits of its territorial sea with adjacent States, ${ }^{4}$ also excluded warships and crafts used by the police and customs from the scope of its application. ${ }^{5}$ Reference was made to the UNCLOS to define 'territorial sea' and the scope of application of the Convention and its Protocol. The Convention is therefore not limited to offenses committed on the high seas or in an exclusive economic zone. It applies to offenses committed in maritime zones under the territorial sovereignty of coastal states (territorial sea and archipelagic waters) as well as in maritime zones outside the territorial sovereignty of coastal states (high seas or exclusive economic zone).

Article 3(1) of the Convention defined offences under the Convention to include acts of seizure of ships, violence against persons on board ships, endangering safe navigation or causing damage or destruction to ships, destroying maritime navigation facilities, and injuring or killing any person in connection with the commission of offences under the treaties. States parties are required to make the acts criminal offences under their domestic law punishable by serious penalties. ${ }^{6}$

The Fixed Platforms Located on the Continental Shelf Protocol to the Convention 1988 also defined 'fixed platforms' and the 'continental shelf' in relation to UNCLOS. As a necessary appendage to the 1988 SUA Convention, the Protocol stipulates in its opening Article that the provisions of Articles 5 and 7 and of Articles 10-16 of the 1988 SUA Convention shall also apply mutatis mutandis to the offences created in Article 2 of the Protocol, and defines the locations as either on board ships or against fixed platforms located on the continental shelf. Article 1(3) defines a fixed platform as 'an artificial island, installation or structure permanently attached to the seabed for the purpose of exploration or exploitation of resources or for other economic purposes.'

Very much in line with the SUA Convention, Article 2 outlines the various categories of offences committable under the Protocol. Again, offences relating to seizure, damage, injury and death are all covered. Article 3 deals with jurisdictional matters while Article 4 preserves the rules of international law pertaining to fixed platforms located on the continental shelf.

\subsection{Protocol to the Convention for the Suppression of Unlawful Acts against the Safety of Maritime Navigation (2005 SUA Convention)}

The continued vulnerability of maritime transport to terrorist attacks was demonstrated by the bombing in February 2004 of the vessel SuperFerry $14 .^{7}$ Furthermore, after the use of unlawfully seized aircraft as impact and incendiary weapons in terrorist attacks on World Trade Centre, New York, the United States in September 2001 (9/11) and the use of an explosive laden ship to attack the oil tanker Limburg in 2002, the IMO Legal Committee produced draft amendments to the 1988 SUA Convention and its Fixed Platforms Located on the Continental Shelf Protocol. The Fixed Platforms Protocol, in particular, was developed as a direct response to the

\footnotetext{
${ }^{1}$ SUA Convention, 1988, Adopted in Rome, 10 March, 1988; entry into force March 1992. 164 State Parties (Convention), 151 States Parties (Protocol).

${ }^{2}$ Counter-Terrorism Legal Training Curriculum, 6

${ }^{3}$ Article 5(6), 1988 SUA Protocol.

${ }^{4}$ Article 4(1), SUA Convention 1988.

${ }^{5}$ Article 2(1), SUA Convention 1988.

${ }^{6}$ Article 5, SUA Convention 1988.

${ }^{7}$ See Table 1.
} 
9/11 events with the broadening of the list of offences covered by the original SUA to include the use of a vessel as a weapon as well as a mode of transporting weapons of mass destruction. ${ }^{1}$

Amendments to the 1988 SUA Convention and the 1988 Fixed Platforms Protocol were adopted in London, United Kingdom, on 14 October 2005 at a Diplomatic Conference on the Revision of the SUA Treaties. ${ }^{2}$ The $^{2}$ amendments were effected through Protocols (the Protocol to the Convention for the Suppression of Unlawful Acts Against the Safety of Maritime Navigation 2005 and the Protocol to the Fixed Platform Protocol 2005).

According to its Article 15, the Protocol of 2005 to the Convention for the Suppression of Unlawful Acts against the Safety of Maritime Navigation is to be read and interpreted between its states parties as a single instrument with the 1988 Convention. The new 2005 provisions and the revised articles of the 1988 Convention are called the 'Convention for the Suppression of Unlawful Acts against the Safety of Maritime Navigation, 2005 (2005 SUA Convention).'

The 2005 SUA Convention amends the original treaty by broadening the list of offences to include, inter alia, the offence of using a ship itself in a manner that causes death or serious injury or damage and the transport of any explosive or radioactive material, any Biological, Chemical and Nuclear (BCN) weapon or any equipment, materials or software that significantly contributes to the design, manufacture or delivery of a BCN weapon, with the intention that it will be used for such purpose. It also introduces provisions for the boarding of ships where there are reasonable grounds to suspect that the ship or a person on board the ship is, has been, or is about to be, involved in committing an offence regulated by the Convention. The Protocol of 2005 to the Protocol for the Suppression of Unlawful Acts against the Safety of Fixed Platforms Located on the Continental Shelf (2005 Fixed Platforms Protocol) extends the scope of provisions on the new offences to fixed platforms located on the continental shelf, as appropriate. Only States Parties to the 1988 SUA Convention can become Parties to its 2005 Protocol. ${ }^{3}$ Only Parties to the 2005 Protocol to the SUA Convention can become Parties to the 2005 Fixed Platforms Protocol. ${ }^{4}$ The IMO Secretariat prepared the consolidated texts of the 1988 SUA treaties, as amended by the 2005 Protocols, for the purpose of facilitating their incorporation into national law.

One of the significant aspects of the 2005 SUA Convention is that it broadens the list of offences by adding three new categories of new offences. The first category of new offenses concerns acts of maritime terrorism such as using a ship as a weapon or as a means to carry out a terrorist attack. ${ }^{5}$ These new offences require specific knowledge and intent. They also require a 'terrorist motive'-the purpose of the acts must be to intimidate a population or compel a government to do or abstain from doing an act. ${ }^{6}$ These new offences update the categories of acts that might endanger the safety of ships engaged in international maritime navigation.

The second category of new offences are non-proliferation offences that are intended to strengthen the international legal basis to impede and prosecute the trafficking on the high seas in commercial ships of $\mathrm{BCN}$ (Biological, Chemical and Nuclear) Weapons, their delivery systems, and related materials. The nonproliferation provisions require States Parties to criminalize transport on the high seas of BCN and certain related materials, as well as nuclear materials and equipment. ${ }^{7}$ This category of new offenses goes beyond the scope of the 1988 SUA Convention, which dealt only with acts that threaten the safety of maritime navigation. It establishes a new tool to combat the proliferation of $\mathrm{BCN}$.

The third category of new offences establishes a new tool for dealing with persons who commit offences under the other United Nations terrorism conventions. It makes it an offence to transport any person by sea who has committed an offence under the 1988 SUA Convention, the 2005 SUA Protocol, or any of the other UN Terrorism conventions when intending to assist that person evade criminal prosecution. ${ }^{8}$ This category of offences also goes beyond the scope of the 1988 SUA Convention, which was founded exclusively on acts that endangered the safety of maritime navigation. This offense also requires specific knowledge and intent to ensure

\footnotetext{
${ }^{1}$ Article $3 b i s(1)(a)$, Fixed Platforms Protocol 2005

${ }^{2}$ The Protocol to the Convention for the Suppression of Unlawful Acts against the Safety of Maritime Navigation 2005 and the Protocol to the Fixed Platform Protocol 2005 were adopted in October 2005 and entered into force on the 28 July, 2010. 33 States Parties.

${ }^{3}$ Article 17(4), SUA Convention 2005.

${ }^{4}$ Article 5, Fixed Platforms Protocol 2005

${ }^{5}$ Article $3 b i s(1)(a)$, SUA Convention 2005.

${ }^{6}(\mathrm{n} 43) 13$

${ }^{7}$ Article 3 bis(1)(b), SUA Convention 2005.

${ }^{8}$ Article 3ter, SUA Convention 2005.
} 
that innocent seafarers and masters are not made criminals. The UN terrorism conventions concerned are listed in Annex I to the Convention.

There is also the obligation of States Parties to furnish evidentiary assistance. Article 12 of the 1988 SUA Convention establishes that State Parties shall afford one another the greatest measure of assistance in connection with criminal proceedings. The 2005 SUA Convention adds provisions on transfer of offenders serving sentence in a State Party to another State Party for the purposes of identification, testimony or provision of assistance in obtaining evidence for the investigation or prosecution of offences set forth in the convention.

Other key features of the 2005 SUA Convention are the imposition of liability (criminal, civil or administrative) on legal entities in Article 4 of the SUA 2005 Convention in view of the new offences created in Articles 3 ter and 3 quater which are likely to involve shipping companies, freight forwarders, manufacturers and other legal entities, and masters of vessels or other responsible persons ${ }^{1}$; adding of boarding and search rules and safeguards to the 1988 SUA Convention; and Article 11 bis of the 2005 SUA Convention which expressly excludes the possibility of a State Party applying the political offence exception to offences established by the SUA Convention to deny requests for extradition or mutual legal assistance.

\subsection{SUA Conventions and Universal Jurisdiction}

The 2005 SUA Convention is one of three conventions adopted by the United Nations to confer universal jurisdiction on states in order to enable them exercise control over persons, situations and events outside their territory or where there is no territorial linkage or nationality. The other two are the 1988 United Nations Convention Against Illicit Traffic in Narcotic Drugs and Psychotropic Substances ${ }^{2}$ and the 2000 United Nations Convention against Transnational Organized Crime. ${ }^{3}$ States parties are obliged under the above conventions to enact national laws which would create relevant offences, and confer mandatory and optional grounds for jurisdiction in respect of the offences so as to have a jurisdictional well where authority can be exercised irrespective of territorial limit. Such domestic legislations shall also consider the treaty as an extradition treaty for the relevant offences where domestic legislation requires extradition treaty before extradition, and to extradite or submit an offender for prosecution in his own state. States Parties shall also remove the political exception rule to extradition for relevant offences in the domestic law. ${ }^{4}$

The treaties came into being following the inability of the 1982 United Nations Convention on the Law of the Sea (UNCLOS) to adequately address emerging pirate and terrorist threats in the late 1980s and early 1990s. The Italian cruise ship Achille Lauro incident, especially, fell outside the scope of the definition of piracy under Article 101 of the Convention leading to calls for treaties that would adequately address it.

The right of states to prosecute a person for criminal acts at their domestic courts derives from the concept of jurisdiction. In general international law, 'jurisdiction' refers to the power of a state to regulate conducts. This power derives from the sovereignty of the state and manifests itself through the state's authority to prescribe laws (prescriptive jurisdiction), enforce them (executive jurisdiction) and adjudicate (judicial jurisdiction).

However, in certain cases, a state might have an interest in exercising its jurisdiction extraterritorially, that is, with regards to acts committed outside its territory. This is particularly evident in the case of piracy and terrorist attacks. Such extra-territorial exercise of jurisdiction is referred to as 'universal jurisdiction.' The principle of universal jurisdiction is classically defined as a 'legal principle allowing or requiring a state to bring criminal proceedings in respect of certain crimes irrespective of the location of the crime and the nationality of the perpetrator or the victim. ${ }^{5}$ This principle derogates from the ordinary rules of criminal jurisdiction requiring a territorial or personal link with the crime, the perpetrator or the victim. Universal jurisdiction is the power granted to all sovereign states to exercise control over persons or events in order to ensure that there is a basis for taking positive action even though there is no territorial linkage or nationality. For universal jurisdiction to apply, it is necessary for the act to occur outside the jurisdiction of a state.

\footnotetext{
${ }^{1}$ Article 5, SUA Convention 2005.

${ }^{2}$ Adopted in Vienna, 20 December 1988, entered into force 11 November 1990. 189 State-Parties.

${ }_{3}^{3}$ Adopted in New York, 15 November 2000, entered into force 29 September 2003. 185 State Parties.

${ }^{4}$ L Onoja, 'Jurisdictional Wells in International Law: The Relevance in the Fight Against Corruption in Nigeria,' in Agada, Akogwu, ed.; Combating the Menace of Corruption in Nigeria: A Multi-Disciplinary Conversation, (Black Tower Publishers, Awka, Anambra State, 2019) 161.

${ }^{5}$ X Philippe, 'The Principles of Universal Jurisdiction and Complementarity: How Do the two Principles Intermesh?' (2006) (88) International Review of the Red Cross 862, 377.
} 
Certain crimes pose so serious a threat to the international community as a whole that states have a logical and moral duty to prosecute an individual responsible. Therefore, no place should be a safe haven for those who have committed genocide, crimes against humanity, extrajudicial executions, war crimes, torture and forced disappearances, piracy, drug trafficking and terrorism. Universal jurisdiction allows states or international organizations to claim criminal jurisdiction over an accused person regardless of where the alleged crime was committed, and regardless of the accused's nationality, country of residence, or any other relation with the prosecuting entity. Crimes prosecuted under universal jurisdiction are considered crimes against all, too serious to tolerate jurisdictional arbitrage. ${ }^{1}$

The concept of universal jurisdiction is premised on the fact that the crime is one that affects the common interest of the community of states and, therefore, all states have an interest to combat that crime. The concept of universal jurisdiction is therefore closely linked to the idea that some international norms are erga omnes, or owed to the entire world community, as well as the concept of jus cogens-that certain international law obligations are binding on all states.

The growing principle of universal jurisdiction has enabled for the trial and prosecution of suspects in any country irrespective of where the offence is committed.

Piracy is the oldest and one of the very few crimes where universal jurisdiction had been recognized under customary international law long ago. Universal jurisdiction was historically justified because pirates are considered to be hostes humani generis, which means enemies of all mankind. Similar criteria should be applied to terrorists as they are also a threat to all states. However, while piracy and terrorism at sea have many similarities and are both forms of violent interfering with shipping, there is a marked difference between the goals of pirates and terrorists: pirates seek financial gain and terrorists strive for a political or ideological aim. Does this fact justify a different legal approach in the sense that the SUA instruments are not applicable to piracy? $^{2}$

Even though the modifying SUA instruments retained the term "unlawful acts", it was understood that the object and purpose of the convention was to deal with acts of terrorism and to provide a legal framework for the apprehension and prosecution of alleged terrorists. The original 1988 SUA-Convention and Protocol addressed the danger of terrorism at sea for the first time. The SUA instruments constitute an important milestone in the development of an international anti-terrorist legislation. These and similar conventions were the result of dealing with international terrorism in a wide variety of fora and with a big number of international instruments. The 2005 amendments to the two instruments have significantly expanded their scope by providing an international treaty framework for combating and prosecuting individuals who use a ship as a weapon or means of committing a terrorist attack, or transport by ship terrorists or cargo intended for use in connection with weapons of mass destruction. ${ }^{3}$

\subsection{Ratification And Domestication Of The 2005 SUA Convention By Nigeria}

Under Section 12(1) of the Constitution of the Federal Republic of Nigeria 1999 (as amended), international treaties entered into by Nigeria have no force of law except to the extent to which they have been enacted into law by the National Assembly. Nigeria domesticated the Convention through the Merchant Shipping Act, 2007 (MSA). ${ }^{4}$ Article 3 of the 1988 SUA Convention and its Protocol (which criminalized maritime-related terrorist acts) was also included in the country's Terrorism (Prevention) Act, $2011{ }^{5}$ and Terrorism (Prevention)(Amendment) Act, 2013. ${ }^{6}$ In 2019, Nigeria enacted a stand-alone Suppression of Piracy and Other Maritime Offences Act, 2019 to give effect to the 2005 SUA Convention in Nigeria.

The ratification of the Convention and domestication by Nigeria is informed by a number of considerations. Nigeria is one of the coastal states on the Gulf of Guinea which is one of the three prime global pirate hotspots. ${ }^{7}$

\footnotetext{
${ }^{1}$ Wikipedia. accessed 3 August, 2021

${ }^{2}$ R A Durler, 'The New SUA Protocols: Development, Contents and Scope,' lecture delivered at the International Maritime Law Institute on April 2, 2015.

${ }^{7}$ The other two being the Gulf of Aden and the Malacca Strait. Piracy incidents have, however, reduced considerably on these two shipping routes and the Gulf of Guinea now accounts for over 80 percent of global piracy incidents.
} 
The country is the worst affected with violent gangs that prey on ships at anchor and those navigating through her territorial waters and the high seas with fatalities being recorded. ${ }^{1}$ Nigeria experienced over 293 pirate attacks between 2003 and 2008. ${ }^{2}$ Although there has been a reduction in the number of recorded pirate attacks globally since 2008, with the number of actual and attempted piratical attacks in 2017 and 2018 standing at 180 and 201 in 2017 and 2018, respectively, Nigeria recorded an astounding 48 incidents in 2018, the highest for any country in the world. ${ }^{3}$ Somalia had only two incidents within the period. These attacks have affected freight and insurance premiums on cargo destined for Nigeria. ${ }^{4}$

Piracy and armed robbery at sea have severely constrained shipping in Nigeria. Ship owners are now forced to arrange and pay for armed guards to escort vessels in and out of berth thereby incurring additional costs (of between $\$ 30,000$ and $\$ 50,000$ per vessel per trip) on the eastern flanks of the nation's waterways. ${ }^{5}$ The carrying of armed guards and firearms for personal protection or protection of a ship is only 'discouraged' by the International Maritime Organization (IMO), not forbidden. ${ }^{6}$ But it has been a vexed issue in Nigeria because of the additional costs it adds to shipping in the country.

Secondly, both customary international law and the Vienna Convention on the Law of Treaties recognize a duty known by the Latin words 'pacta sunt servanda' meaning that agreements must be observed in good faith. In dualist countries, that is, those which require legislation to translate treaty obligations into domestic law, observance of the maritime instruments in good faith means that the necessary legislative implementation of treaty obligations should precede or be contemporaneous with adoption of the international instrument. Nigeria, as part of the international community has an obligation to ratify and domesticate important treaties like the 2005 SUA and its Fixed Platform Protocol for her own security and the security of global maritime transport and facilities. In the US $v S h i,{ }^{7}$ the conviction of Shi for unlawful acts at sea was upheld by the Supreme Court of the United States because the need of the United States to be able to fulfil treaty obligations and the historical need to deal with crimes on the high seas provided a constitutional justification for the domestic statute under which Shi was properly prosecuted.

Thirdly, piracy manifests as low-intensity insurgency when it comes to oil exploration. Oil installations in Nigeria have come under attack by pirates and terrorists with oil production in Nigeria dropping by 20 percent at the peak of attacks in 2006 costing the Nigerian economy approximately US\$202 million. ${ }^{8}$ Although most of the attacks were on onshore facilities, the stakes went up in 2008 when the Bonga oil platform, an FPSO producing about 202,000 barrels of crude oil per day and located about 120 nautical miles offshore Nigeria, was attacked by a militant group, the Movement for the Emancipation of the Niger Delta (MEND). The operator of the platform, Shell, was forced to shut it down for three weeks. MEND has been classified as a terrorist organization. ${ }^{9}$ Nigeria is at present estimated to be losing about one million barrels of crude oil per day due to attacks on its oil installations and oil theft. ${ }^{10}$

\footnotetext{
${ }^{1}$ Two Dead in Gulf of Guinea Hijackings, HIS Safety at Sea, Daily News E-mail (12 February 2015)

${ }^{2}$ R Haywood, and R Spivak, 'Maritime Policy, Routledge, (New York, United States, 2012)

${ }^{3}$ Maritime Governance Brief, Centre for Maritime Law and Security, $(1,2,2019) 4$

${ }^{4}$ L Otto, 'Piracy in Gulf of Guinea: Attacks on Nigeria's Oil Industry Spill Over in the Region,' (2011). http://www.consultancyafrica.com/index. accessed 20 August, 2021

${ }^{5}$ Thisday (Nigeria, 1 November, 2019) 25.

${ }^{6} \mathrm{MSC} / \mathrm{Circ} .623$

7525 F. $3^{\text {rd }} 709$ (9 $9^{\text {th }}$ Cir. 2008).

${ }^{8}$ L Otto, (n62) 19

${ }^{9}$ J Kraska, James (n23) 8

${ }^{10}$ Buhari: Victory Offers Mixed Messages for Gulf of Guinea Shipping, HIS Maritime Safety at Sea, Daily News E-Mail (Nigeria, 2 February 2013).
} 
Table 2: Some of Nigeria's Offshore Oil Fields

\begin{tabular}{|l|l|l|l|l|l|l|}
\hline \multicolumn{7}{|c|}{ BONGA (Dev. Cost-\$3.6bn) } \\
\hline Operator & Partners & $\begin{array}{l}\text { Discovery } \\
\text { (Year) }\end{array}$ & $\begin{array}{c}\text { Commence } \\
\text { Production } \\
\text { (Year) }\end{array}$ & $\begin{array}{c}\text { Current } \\
\text { Production } \\
\text { (Oil) (bpd) }\end{array}$ & Platform & $\begin{array}{c}\text { Location } \\
\text { Offshore }\end{array}$ \\
\hline Shell & $\begin{array}{l}\text { Exxon, } \\
\text { Agip, ELF }\end{array}$ & 1996 & 2005 & 202,000 & FPSO & $\begin{array}{l}120 \mathrm{~km} / \\
75 \mathrm{~nm} *\end{array}$ \\
\hline \multicolumn{7}{|c|}{ ERHA (Dev. Cost-\$3.6bn) } \\
\hline ExxonMobil & Shell & 1999 & 2006 & 150,000 & FPSO & $97 \mathrm{~km} / 60 \mathrm{~nm}$ \\
\hline \multicolumn{7}{|c|}{ AGBAMI (Dev. Cost-\$3.5bn) } \\
\hline Chevron & $\begin{array}{l}\text { Statoil, } \\
\text { Petrobas, } \\
\text { Famfa }\end{array}$ & 1999 & 2008 & 250,000 & FPSO & $70 \mathrm{~nm}$ \\
\hline
\end{tabular}

\subsection{Suppression of Piracy and Other Maritime Offences Act, 2019}

The Suppression of Piracy and Other Maritime Offences Act, 2019 (POMO Act) is the primary legal instrument for the suppression of unlawful acts against the safety of maritime navigation in Nigeria. The Act gives effect to the relevant provisions of several international conventions already ratified by Nigeria. ${ }^{1}$ It is significant because it has ended the controversy around whether the crime of sea piracy is defined in any local legislation; and bestows on the Federal High Court exclusive jurisdiction to determine matters of piracy, armed robbery and other unlawful acts at sea. ${ }^{2}$

Prior to the enactment of the Act, the prosecution of parties suspected of sea piracy was problematic in Nigeria, as there appeared to be no domestic statute which defined the crime. Under Section 36(12) of the Constitution, no party may be convicted of a criminal offence unless such offence is defined by an existing law. Although Section 216(h) of the Merchant Shipping Act (MSA) 2007 provides that the SUA Convention, 1988 and the protocol thereto have applied since the MSA's commencement, there were doubts among maritime stakeholders as to whether Section 216(h) thereof sufficiently domesticated the SUA Convention as required by the Constitution. Section 3 of the POMO Act has laid this issue to rest by defining 'piracy' as any:

(a) illegal act of violence, act of detention or any act of depredation, committed for private ends by the crew or any passenger of a private ship or private aircraft and directed

(i) in International Waters against another ship or aircraft or against a person or property on board the ship or aircraft, or

(ii) against a ship, aircraft, person or property in a place outside the jurisdiction of any state;

(b) act of voluntary participation in the operation of a ship or of an aircraft with knowledge of facts making it a pirate or ship aircraft; (c) act of inciting or of intentionally facilitating an act described in subparagraph (a) or (b) of this section.

Notably, the above definition accords, seemingly, with the universal jurisdiction principle espoused in the United Nations Convention on the Law of the Sea 1982, whereby states may-in accordance with their municipal lawsarrest and prosecute persons, ships or aircraft suspected of committing piracy regardless of whether the pirate or attacked ship flies a foreign flag or has a foreign crew. ${ }^{3}$ The definition also covers violent acts committed against property other than ships, such as aircraft and floating and fixed platforms in the Nigerian Exclusive Economic Zone.

Section 4 of the POMO Act lists 18 maritime offences and unlawful acts at sea, which include armed robbery at sea and acts other than piracy committed within Nigeria or its maritime zone. Such acts include the hijacking of a ship, aircraft or fixed or floating platform; the destruction or vandalism of a ship, installation or navigation facility; or interference with the operation of a ship, installation or navigation facility.

${ }^{1}$ UNCLOS and the SUA Convention and its Protocols.

${ }^{2} \mathrm{~V}$ Onyegbado (n4) 2

${ }^{3}$ Article 105, UNCLOS. 
Under Section 5(2) of the POMO Act, the Federal High Court, to the exclusion of all other courts, has jurisdiction to hear and determine any matter under the act. In addition, Section 10 provides that, notwithstanding the provisions of any other act, any person who commits or attempts to commit, facilitates, aids, abets, conspires or participates in an act of piracy or any maritime offence or unlawful act under the act will be liable, on conviction, to any penalty or punishment provided for under the Act. The combined effect of these two provisions appears to be that where an act constitutes an offence under the law, it cannot be prosecuted in any way other than as set out in the POMO Act. Thus, for example, the trial of a case of armed robbery committed on board a ship within Nigerian waters may not be validly heard and determined in the High Court of any State of Nigeria or the Federal Capital Territory despite the general jurisdiction of those courts to try cases of armed robbery. The admiralty jurisdiction of the Federal High Court covers ships, whether or not their owners reside or are domiciled in Nigeria and all maritime claims notwithstanding where the cause of action arose from. The POMO Act is in tandem with Section $251(1)(\mathrm{g})$ CFRN, Section 7 of the Federal High Court Act and Section 1 of the Admiralty Jurisdiction Act, 1991 which confer on the Federal High Court the exclusive jurisdiction to hear and determine any question relating to a admiralty. The major implication of these provisions is that, where a case that falls within the admiralty jurisdiction of the Federal High Court or a piracy matter is filed in a Court other than the Federal High Court, the suit will be incompetent and the court will lack jurisdiction to hear and determine the matter. Consequently, any order made by such court will be null and void for being made without jurisdiction. Both the Admiralty Jurisdiction Procedure Rules, 1993 and the Federal High Court (Civil Procedure) Rules, 2000 regulate the practice and procedure in maritime claims in the Federal High Court. ${ }^{1}$

One aspect of the act that is commendable is the fact that it empowered Nigerian Maritime and Safety Agency (NIMASA) to prosecute offences under POMO Act albeit with the consent of the Attorney General. Section 5 (1) provides that the Attorney General; any law officer so designated by the Attorney General; or the Nigerian Maritime Administration and Safety Agency (NIMASA) with the Attorney General's consent are empowered to prosecute offences under POMO Act.

Section 12 provides that any person who commits an act of piracy, armed robbery at sea or any other unlawful act under POMO Act, whether or not the person was armed with a firearm or other weapon during the commission of the offense shall be liable on conviction to life imprisonment and payment of N50, 000,000.00 (Fifty Million Naira) and in addition to restitution to the owner.

As the first country in the region to pass an anti-piracy law, Nigeria's effort is commendable. The POMO Act's strengths are, among others, its definition of piracy which is in line with UNCLOS, and its specific punishments for violations. However, more need to be done in order to regulate fishing on the country's waters, especially to control the movement of the proceeds of illegal fishing. ${ }^{2}$ The Nigeria's anti-piracy law does not provide adequate measures for the regulation of fishing and other living animals that are resourceful to the Country's economy. The POMO Act also ought to have captured what the financial institutions are doing, how monies are transferred from one country to another - proceeds of the crime of illegal fishing - and again monitor the markets. Questions such as "where are they selling these products?" need to be asked and answered. One good thing with ocean resources, a prawn can tell its own story, where is it caught. It is just a little analysis and you will get all the information. This is an effective way of monitoring illegal fishing. In order to tackle or achieve this, the Nigerian anti-piracy law needs to be amended to capture the regulation of fishing and protection of sea/ocean resources. ${ }^{3}$

According to the $\mathrm{ICC}^{4}$ International Maritime Bureau, actual and attempted piracy and armed robberies against ships on Africa's West Coast rose ${ }^{5}$ from 47 in 2011 to 64 in 2019. In 2019 the United Nations Office on Drugs and Crime reported that between 2015 and 2017, the total economic cost of piracy, kidnapping and armed robbery at sea incurred by all stakeholders involved in countering these activities, including Nigeria, was US $\$ 2.3$ billion. ${ }^{6}$

\footnotetext{
${ }^{1}$ L Nwaeze, Admiralty Jurisdiction in Nigeria, https://www.hg.org/legal-articles/admiralty-jurisdiction-in-nigeria-21404 accessed 22 August, 2021

2 https://www.worldstagegroup.com/maritime-safety-nigeria-on-path-of-progress-with-anti-piracy-law-un/ accessed 24 August, 2021

${ }^{3}$ Ibid 73

${ }^{4}$ International chamber of commerce

${ }^{5}$ https://www.icc-ccs.org/reports/2019_annual_piracy_report accessed 22 August, 2021

6 https://ww.unodc.org/nigeria/en/press/west-africa-loses-2-3-billion-to-maritime-crime-in-three-years-as-nigeria--unodc-
} 
Since the Act was passed however, maritime crime has continued unabated. According to The Economist, piracy in the region is 'primarily a Nigerian problem' because pirates operate ${ }^{1}$ mostly 'out of the labyrinthine waterways in the Niger Delta.' In December 2019, four armed robberies occurred in Nigeria's waters. On 2 January 2020, three seafarers were kidnapped and four security personnel killed on a dredger off Forcados Terminal in Nigeria. ${ }^{2}$

Sometimes in February 2020, two international shipping groups, the Baltic and International Maritime Council and the International Association of Independent Tanker Owners, threatened to report Nigeria to the United Nations. The groups wanted clear action to be taken to stop pirate attacks against their vessels and personnel.

This raises questions about Nigeria's capacity to implement its new law, and detect and prosecute crimes. Of course, it takes time for new laws to show results, but part of the problem may lie with the POMO Act itself.

It is a standalone law that operates independently of other domestic laws such as those governing firearms, kidnapping and money laundering. This limits its effectiveness in the face of evolving crimes like piracy. It will also make complying with international conventions such as UNCLOS and SUA difficult. Nigeria's anti-piracy law operates independently of domestic laws and maritime regimes.

Given that piracy is a transnational crime, combatting it requires more than national efforts. After the Yaoundé Code of Conduct was reviewed in 2017, maritime laws or amendments to penal codes were expected throughout West Africa to standardize legal regimes. Only Nigeria has since passed anti-piracy legislation, and even then, its standalone nature means the law won't help coordinate piracy responses in the region. This is a loophole in the POMO Act that needs to be amended to protect and cover other regions because piracy has the actual or potential effect across national borders which offend fundamental values of international community. Nigeria as a member of various international communities like African Union (A.U.), the Economic Community of West African States (ECOWAS) and so on ought to have put into consideration measures to be taken to protect and regulate piracy within the West African Sub-region.

Another challenge with the POMO Act is its lack of clarity on roles and responsibilities. There are conflicts amongst ministries and agencies that have the responsibilities of coordinating maritime activities and security. That is because there is no clear cut delineation of functions to the existing agencies. There functions, powers and duties conflict with the other. The discordance in the relationship among the government agencies, limits the effectiveness in carrying out their duties such as regulation, protection, monitoring, compliance and enforcement of the anti-piracy law. Section 17(3) says 'law enforcement and security agencies' will be responsible for gathering intelligence, patrolling waters and investigating offences. But the law isn't specific on which law enforcement agencies are responsible for these functions - an oversight that may deepen inter-agency rivalry. The Armed Forces Act of 1993 makes Nigeria's Navy responsible for securing the country's maritime domain. But Section 17(1) and (2) of the POMO Act seems to have tasked the Nigerian Maritime Administration and Safety Agency with coordinating all maritime activities and security including 'to prevent and combat piracy, maritime offences and any other unlawful acts prohibited by this Act'. The law also does not provide for strengthening maritime agencies. Areas that need attention are their ability to control private maritime security operatives, clarity of mandates and responsibilities, and enhanced human and institutional capacity. This matters because it is fragile institutions and irregular practices rather than the absence of laws that account for Nigeria's weak maritime security. Worryingly, the POMO Act has no provisions against corrupt practices by Nigeria's maritime agencies, which also fuel piracy. ${ }^{3}$ Lack of clarity on roles and responsibilities may deepen inter-agency rivalry and this has to be corrected and addressed in the POMO Act.

Most fundamentally, the law doesn't deal with proceeds from piracy, kidnapping and armed robbery at sea. Although it provides, as punishment, the 'forfeiture to the Federal Government of Nigeria whatever the person obtained or gained from commission of the crime,' this may not be adequate as a deterrent. The proceeds of piracy are connected to illicit financial activities such as money laundering, corruption, tax and document fraud.

rally-multi-national-efforts-to-thwart-piracy-in-the-gulf-of-guinea.html accessed 25 August, 2021

$1<$ httpseconomist.com/international/2019/06/2019/the-gulf-of-guinea-is-now-the-worlds-worst-piracy-hotspot> accessed accessed 25 August, 2021

https://www.seatrade-maritime.com/ship-operations/three-seafarers-kidnapped-four-securitypersonnel-killed=nigerianpirate-attack accessed accessed 26 August, 2021

${ }^{3}$ https://www.baselgovernance.org/sites/default/files/2019-02/ accessed 26 August, 2021 
Combatting piracy must go beyond the mere forfeiture of gains and imprisonment. A nuanced approach is needed to deal with related crimes, including the transfer and use of proceeds and some form of recourse, especially for victims of armed robbery and kidnapping. ${ }^{1}$

Piracy also involves the illicit act of trafficking of guns, drugs and people, as well as armed robbery. Yet the law doesn't deal with pirates' weapons, how they are procured, the process of recruiting pirates, and those who provide pirates with safe havens. In Kenya, for instance, the anti-piracy law covers attacks, money laundering and organized crime. ${ }^{2}$

To achieve its purpose, Nigeria's anti-piracy law should be amended to align with regional maritime legal regimes such as the Yaoundé Code of Conduct as well as domestic legislation dealing with kidnapping, firearms and money laundering. The role of the navy as the lead agency in maritime security should be clarified, and collaboration among relevant agencies strengthened. The law also needs to deal with the proceeds of piracy and related crimes including corruption.

Section 19 of the Act provides that a fund known as the Piracy and Other Maritime Offences Fund (POMO Fund) shall be created by the Nigerian Maritime and Safety Agency (NIMASA). The POMO fund is to be used for the implementation of the Act and the Fund shall be credited from money approved by the Federal Government for the implementation of the Act; gifts, financial contributions by beneficiaries of the services of the maritime enforcement agencies; $35 \%$ of the proceeds of sales of any property seized and anything forfeited under the Act including instruments used in the commission of crimes and criminal activity under the Act; the contribution from the maritime fund under NIMASA Act; and contribution from the Cabotage Vessel Financing Fund (CVFF) under the Cabotage Act 2003. Furthermore, the POMO fund is to be managed by NIMASA. It is hoped that the POMO fund will not suffer the same fate as the undisbursed Cabotage Vessel Financing Fund (CVFF) created under the Cabotage Act. Suffice to say that the POMO fund is to be disbursed judiciously for the successful implementation of the POMO Act 2019.

With the full adaptation of the definition of piracy under Article 101 of UNCLOS, the challenges associated with that definition were also adopted. For instance, section 4 of POMO Act provides that for piracy to be established, the act must be committed for private ends or for personal gain. However, any acts that are politically motivated do not fall within the definition of piracy. This principle is flawed because, in Nigerian political climate, political rivals could go as far as committing a criminal act of violence against a ship or crewmen, unfortunately, it will not amount to piracy.

Another pitfall observed, is the failure of the Act to expressly define a ship or what constitutes a ship. A similar lacuna was also created in the Cabotage Act 2003. The failure of the Cabotage Act to expressly describe an oil rig as a ship has been used by foreign shipowners as an avenue for contesting the statutory powers of NIMASA to levy its statutory fees on oil rigs employed by these shipowners in their drilling operations until the Court finally interpreted the act to include oil rigs that are propelled. The issue of what constitutes a ship could have easily been averted if the definition given by the Act was all-encompassing and sufficient to cover all ships like the Jones Act 1929 did. It is hoped that this lacuna will not affect the effective prosecution of offenses under the Act.

Section 4(g) of the POMO Act, 2019 provides that it is an offense to receive proceeds from the crime of piracy, armed robbery against ships and other maritime offenses at sea. The Act expressly lumped individuals receiving proceeds from the crimes under the Act and Corporate entities such as banks and other financial institutions. There is a need to revisit this section because the proceeds of crimes including maritime crimes usually find its way to banks and other financial institutions without the banks knowing the actual source of the funds. With the enactment of this Act, banks and other financial institutions are advised to upgrade their 'know your customer' (KYC) tools and procedure.

The Act under section 12 (1) provides that any person who commits an act of piracy, armed robbery at sea or any other unlawful act under the Act, whether or not the person was armed with a firearm or other weapon during the commission of the offense shall be liable on conviction to life imprisonment and a fine of N50,000,000.00 (Fifty Million Naira) and restitution. However, section 12 (2) also provides that if during the commission of an armed

${ }^{1}$ M Ogbonnaya, https://issafrica.org/author/maurice.ogbonnaya accessed 27 August, 2021

${ }^{2}$ https://enactafrica.org accessed 27 August, 2021 
robbery at sea, the offender was in possession of or had under his control any firearm, explosive or BRCN weapon, the offender will be liable on conviction to at least 15 years imprisonment. There is a need to revisit the punishment section because of the disparity and ambiguity.

Another issue is the liability of legal entities. The 2005 SUA Convention imposes liability on legal entities in its Article 4 in view of the new offences created in Articles 3 ter and 3 quater which are likely to involve shipping companies, freight forwarders, manufacturers and other legal entities, and masters of vessels or other responsible persons. Article 5 of 2005 SUA Convention provides that each State Party, in accordance with its domestic legal principles, shall take the necessary measures to enable a legal entity located in its territory or organized under its laws to be held liable when a person responsible for management or control of that legal entity has, in that capacity, committed an offence set forth in the Convention. Such liability may be criminal, civil or administrative.

The above provision is also not included in the POMO Act. There is no corporate liability included in the Act.

Also, the POMO Act, 2019 included 'Radiological' to Biological, Chemical and Nuclear (BCN) weapons. BCN are new non-proliferation offenses introduced by the 2005 SUA Convention and are intended to strengthen the international legal basis to impede and prosecute the trafficking on the high seas in commercial ships of BCN Weapons, their delivery systems, and related materials. The non-proliferation provisions require States Parties to criminalize transport on the high seas of $\mathrm{BCN}$ and certain related materials, as well as nuclear materials and equipment. ${ }^{1}$

The 2005 SUA provides for only BCN weapons. The Suppression of Piracy and Other Maritime Offences Act adds 'Radiological' to BCN making it now BRCN (Biological, Radiological, Chemical and Nuclear) weapons. 'Radiological' is, however, not defined in the Act.

Radiological warfare is any form of warfare involving deliberate radiation poisoning or contamination of an area with radiological sources. The fission products from a conventional nuclear explosive weapon are as much a radiological weapon as weapon solely designed for the purpose of mass radiological warfare. Radiological weapons are normally considered weapons of mass destruction. ${ }^{2}$

What is the difference between 'radiological' and 'nuclear'? the Act does not make the distinction. Since the Act does not define 'radiological,' it is difficult finding out the intention behind the inclusion/addition of 'radiological' to the $\mathrm{BCN}$ weapons in the Act. Adding radiological to BCN weapons, however, seems superfluous and unnecessary.

\subsection{Conclusion}

The Gulf of Guinea is bordered by several states, creating several legal and regulatory complexities in addressing maritime crime. The Suppression of Piracy and Other Maritime Offences Acts (POMO Act) 2019 is very much needed for the protection and securitization of the Nigerian territorial and internal waters in order to continue carrying on with its businesses and maintain global commercial relationship with other nations.

Whilst piracy and other violent incidents at sea is declining globally, it is escalating in Nigeria. In the long run, the root cause of the problem lie further ashore. Near-total collapse of the state in Nigeria has had a corresponding effect on her coastlines. A country that cannot police its hinterlands would not be expected to police its coastlines. State failure in Yemen and Somalia led to escalation and spike in piracy in the Gulf of Aden between 2007 and 2010 before coalition navies of the developed world checked the menace. ${ }^{3}$ Nigeria needs to improve her domestic governance and security architecture. ${ }^{4}$

By criminalizing the offences of piracy, armed robbery against ships, cargo theft and other related maritime offences with stiff punishments, Nigeria will be seen internationally as a nation that has keen interests in maintaining commercial and socio-economic relationship with other nations in order to achieve growth and development. This law will enhance security within her territorial waters and reduce the mayhem and other criminal activities that have engulfed its waters both internally and otherwise.

\footnotetext{
${ }^{1}$ Article 3bis(1)(b), SUA Convention 2005.

${ }^{2}$ Merriam-Webster Dictionary. https://www.merriam-webster.com/dictionary/radiological. Accessed 17/08/2021.

3 'We Are Not the Solution to Piracy, Says Somalia Coalition Navy Chief,'Lloyd's List (25 September, 2008).

${ }^{4}$ L Onoja (n50) 15
} 
Beyond the law, Nigeria must tackle sociological and environmental factors that drive the problem. Militancy and criminality in the Niger Delta manifest in piracy and maritime insecurity. Deliberate policies aimed at these root causes and at reducing the ability of groups to operate at sea, hold the key to defeating piracy in Nigeria and the West African region.

For the medium term, Nigeria should strengthen its legal framework by making necessary amendments to the POMO Act, 2019 in line with the observations made above. 